Jūlija Bistrova, Natalja Lāce

\title{
Uzṇēmumu produktivitāte, finanšu veselība un inovatīvais potenciāls
}

Pēc Solou model̦a ${ }^{1}$ valsts ekonomikas izaugsme var tikt skaidrota ar trīs galvenajiem faktoriem - kapitāla un darbaspēka ieguldījumu un kopējo faktoru produktivitāti (KFP). Kā norāda agrāki pētijumi par ekonomikas izaugsmi, ieguldījumi darbaspēkā un kapitālā spēj izskaidrot mazāk nekā pusi no izaugsmes. ${ }^{2}$ Saskaņāa ar Coelli un citiem ${ }^{3}$ visi faktori ir savstarpēji saistīti un papildina cits citu, radot komplicètu mijiedarbību. Tomēr pēdējos gados, kad arvien svarīgākas uzṇēmējdarbībā kḷusst zināšanas un inovācijas, kad nemateriālie aktīvi uzņēmumu bilancēs bieži vien ir vērtīgāki par fiziskajiem aktīviem, kad pasaule stāv uz nākamas industriālās revolūcijas Industry $4.0^{4}$ sliekšņa, KFP nozīme, pētot ekonomikas izaugsmi, arvien pieaug.

Ir veikts daudz pētijumu, pierādot, ka KFP ir svarīgs faktors ekonomikas tendenču un ekonomiskās izaugsmes skaidrošanā, kā arī ienākuma uz vienu iedzīvotāju veicināšanā dažādās valstīs. ${ }^{5}$ KFP ir arī svarīgs faktors, nosakot atsevišķa uzņēmuma pievienoto vērtību. Šis rādītājs vārētu sniegt pat labāku ieskatu par uzṇēmuma finanšu

1 Solow, R. M. (1957). Technical Change and the Aggregate Production Function. The Review of Economics and Statistics, 39(3), 312-320.

2 Griliches, Z. (1996). The discovery of the residual: a historical note. Journal of Economic Literature XXXIV: 1324-1330.

3 Coelli, T. J., Rao, D. S. P., O’Donnell, C. J., \& Battese, G. E. (2005). An introduction to efficiency and productivity analysis. Springer Science \& Business Media.

4 Marr, B. (2016). Why Everyone Must Get Ready For The $4^{\text {th }}$ Industrial Revolution, Forbes, April 5, 2016. Pieejams: https:/www.forbes.com/sites/bernardmarr/2016/04/05/ why-everyone-must-get-ready-for-4th-industrial-revolution/\#3f4768bb3f90.

5 Beņkovskis, K., Fadejeva, L., Štērers, R., \& Verca, J. (2013). Kopējās faktoru produktivitātes loma Centrālās Eiropas, Austrumeiropas un Dienvidaustrumu Eiropas valstu attīstībā. 
panākumiem un attīstību nekā daži tradicionālie rādītāji, piemēram, darba ražīgums vai rentabilitāte. ${ }^{6}$

Kopējās faktoru produktivitātes jēdziens ir cieši saistīts ar inovāciju koncepciju, ko pierada vairāki empīriski pētījumi, secinot, ka pastāv pozitīva korelācija starp uzṇēmuma produktivitāti un inovāciju potenciālu ${ }^{7,8,9}$, kas parasti tiek uzskatîts par uzṇēmuma konkurētspējas avotu un nacionālās ekonomikas dzinējspēku. Savukārt daži pētnieki apgalvo, ka uzṇēmuma aktivitāte inovāciju jomā (izteikta kā investīcijas pētniecỉbā un attīstībā jeb P\&A, nemateriālo aktīvu lielums, kā arī patentu skaits) pozitīvi korelē ar uzṇēmuma tirgus vērtību un tā finanšu rādītājiem. ${ }^{10,11,12}$

Šà pētijuma mērķis ir apskatīt KFP Latvijas uzn̦ēmumu griezumā, analizējot to atkarībā no nozares un reǵiona, kā arī noskaidrot, vai pastāv saikne starp produktivitāti un uzṇēmuma kapitāla rentabilitātes līmeni, kā arī starp produktivitāti un uzñēmuma operacionālo pelnītspēju. Pètījums papildus skaidro, vai arī Latvijā var likt vienādības zīmi starp uzneēmuma produktivitāti un tā inovatīvo potenciālu. Tā kā Latvijas uzņēmumi neizdala pētniecības un attīstības izdevumus kā atsevišḳu pozīiju finanšu pārskatos, autores pieṇēma ieguldījumus nemateriālos aktīvos kā faktoru, kas varētu noteikt uzṇēmumu inovatīvo potenciālu.

Pētỉjums sniedz zinātnisko ieguldījumu izpētē par KFP uzñēmumu līmenī. Šādu pētijjumu skaits pasaulē ir diezgan ierobežots, jo pētijjumi par KFP tiek veikti pārsvarā makroekonomiskā līmenī. Šì izpēte arī papildina esošo zinātnisko bāzi, kas analizē Latvijas uzṇēmumu produktivitāti.

Autores sniedz esošo teorētisko un empīrisko pētijumu pārskatu par KFP saistību ar uzñēmumu finanšu sniegumu un to inovatīvo potenciālu; apraksta pētījuma metodologiju un datu iegūšanas un apstrādes procesu, izskaidro analīzē iegūtos rezultātus par KFP dinamiku un KFP līmeņa atkarību no reǵiona un nozares un izvērtē uzṇēmumu KFP rādìtāju saistību ar uzṇēmumu kapitāla un operacionālo rentabilitāti.

6 Lieberman, M. B., \& Kang, J. (2008). How to measure company productivity using value-added: A focus on Pohang Steel (POSCO). Asia Pacific Journal of Management, 25(2), 209-224.

7 EBRD. (2014). Transition report. European bank for Reconstruction and Development. Available at: https:/www.ebrd.com/news/publications/transition-report/transition-report-2014.html

8 Hall, B. H. (2011). Innovation and productivity (No. 17178). National bureau of economic research.

9 Verdier, G., Kersting, E., \& Dabla-Norris, M. E. (2010). Firm productivity, innovation and financial development (No. 10-49). International Monetary Fund.

10 Villalonga, B. (2004) Intangible resources, Tobin's q, and sustainability of performance differences. Journal of Economic Behavior \& Organization, 54(2), 205-230.

11 Cho, H. J., Pucik, V. (2006). Relationship between innovativeness, quality, growth, profitability, and market value. Strategic management journal, 26(6), 555-575.

12 Warusawitharana, M. (2008). Research and development, profits and firm value: a structural estimation. Finance and Economics Discussion Series, Board of Governors of the Federal Reserve System, 52. 


\section{Finanšu stāvoklis un kopējā faktoru produktivitāte}

Pašlaik ir pieejams diezgan ierobežots pētījumu skaits, kuros būtu apskatīta produktivitātes saikne ar uzṇēmuma rentabilitātes rādīājiem. Vienu no tiem izstrādājis čehu zinātnieks Machek $^{13}$, kas norāda uz KFP saikni ar uzṇēmuma finanšu rādītājiem (pašu kapitāla rentabilitāte, aktīvu atdeve un apgrozījuma rentabilitāte). Machek secina, ka šì saistība rodas tāpēc, ka KFP tiek aprēḳināta, pamatojoties uz uzṇēmuma pievienoto vērtību, kurai ir pozitīva korelācija ar finanšu rādītājiem.

KFP saikne ar uzṇēmuma kapitāla struktūru un pieeju finanšu resursiem turpretim ir diezgan plaši aprakstīta zinātniskajā literatūrā. Coricelli un citi ${ }^{14}$, pētot Centrālās un Austrumeiropas uzṇēmumus, secināja, ka ir vērojama nelineāra sakarība starp šiem lielumiem, jo KFP pieaug līdz ar finanšu sviras pieaugumu, taču noteikta līmeņa gadījumā, pašu kapitālam turpinot samazināties aktīvu struktūrā, KFP sāk strauji krist. Apjomīgu pētījumu par šo saistību veikuši arī Gomis un Khatiwada ${ }^{15}$, analizējot uzṇēmumus no 100 valstīm un nosedzot 30 gadu periodu. Viṇi apstiprina iepriekš atklāto pozitīvo saikni starp uzṇēmuma finanšu sviru un uzṇēmuma produktivitāti, minot arī to, ka ir vērojama samazināta atdeve no papildu piesaistītiem līdzekḷiem, kas negatīvi atspogul,ojas produktivitātē.

Levine un Warusawitharana ${ }^{16}$ pètījumā par Eiropas uzṇēmumiem norādījuši, ka produktivitāte ir cieši saistīta ar uzṇēmuma ārējas finansēšanas iespējām. Līdz ar to secināms, ka uzṇēmuma produktivitāte ir atkarīga arī no tā, kāda ir valsts finanšu attīstība.

Nevar arī nepieminēt: jo labāk ir attīstīta valsts finanšu joma, jo augstāku KFP uzṇēmumi var sasniegt. ${ }^{17}$ Līdzìgu sakarību atklājuši arī itāḷu zinātnieki, kas norāda uz pozitīvu attiecību starp vietējo iestāžu attīstības līmeni, kā arī sniegto pakalpojumu kvalitāti un uzņēmumu produktivitāti ${ }^{18}$.

13 Machek, O. (2014). The relationship between financial performance and total factor productivity: evidence from the Czech agricultural sector. International Journal of Economics and Finance Studies, 6(2), 57-67.

14 Coricelli, F., Driffield, N., Pal, S., \& Roland, I. (2012). When does leverage hurt productivity growth? A firm-level analysis. Journal of international Money and Finance, 31(6), 1674-1694.

15 Gomis, R., \& Khatiwada, S. (2016). Debt and productivity: Evidence from firm-level data. International Labour Office, Working Paper, No. 15.

16 Levine, O., \& Warusawitharana, M. (2014). Finance and productivity growth: Firm-level evidence. Federal Reserve Board.

17 Han, J., \& Shen, Y. (2015). Financial development and total factor productivity growth: Evidence from China. Emerging Markets Finance and Trade, 51(sup1), S. 261274.

18 Lasagni, A., Nifo, A., \& Vecchione, G. (2015). Firm productivity and institutional quality: Evidence from Italian industry. Journal of Regional Science, 55(5), 774-800. 


\section{Inovatīvais potenciāls un kopējā faktoru produktivitāte}

Pētījumi, kas veikti ar mērḳi atklāt sakarību starp uzṇēmumu produktivitāti un inovācijām, norāda uz nenoliedzamu saikni. Protams, iegūtajos rezultātos ir vērojamas nianses, ja tiek runāts par produktu vai procesu inovācijām, taču nozaru un uzņēmumu līmeņa pētijumi nonāk pie nepārprotamiem secinājumiem.

Nozaru lìmeņa pètijums, ko veica Cameron un citi ${ }^{19}$, secina, ka P\&A ieguldỉjumi sekmē strauju, uz inovācijām balstītu izaugsmi un tādējādi pozitīi ietekmē produktivitāti. Citā pētījumā, kurā analizētas ražošanas nozares 12 valstīs, secināts, ka uzṇēmumu inovāciju sniegumu ietekmējošie P\&A ieguldījumi veicina KFP pieaugumu ${ }^{20}$. Wang un $T s a i^{21}$, pamatojoties uz pètijumu rezultātiem, kas ietvēra 136 Taivānas uzņēmumus, secinājuši, ka investīcijas P\&A lielā mērā nosaka KFP pieaugumu. Tāpat arī vairāki pētījumi uzṇēmumu līmenī atklāj pozitīvu korelāciju starp ieguldījumiem P\&A un KFP pieaugumu: Lichtenberg un Siegel22, analizējot 2000 ASV uzñēmumu, Hall un Mairessee ${ }^{23}$, analizējot 197 franču uzṇēmumus laikposmā no 1980. līdz 1987. gadam, kā arī Smith un citi²4, pētot 226 Dānijas ražošanas uzņēmumus.

Protams, svarīgākais ir nevis P\&A ieguldijumu apjoms, bet gan P\&A procesa efektivitāte, jo tieši inovatīvo produktu un procesu radišana ietekmē kopējo faktoru produktivitāti. Zhao un $\mathrm{Liu}^{25}$, pētot K̦inas uzṇēmumus no 1988. līdz 2009. gadam, atklājuši, ka uzņēmumiem piederošo patentu skaits, kas ir viens no P\&A procesa rezultatīviem rādītājiem, pozitīi ietekmē KFP izaugsmi. Pozitīvā saikne ar produktivitātes pieaugumu īpaši labi redzama pētāmā perioda pēdējā desmitgadē. Cui un $L i^{26}$ veica līdzīgu pētījumu par ASV uzņēmumiem periodā no 1976. līdz 2006. gadam, secinot: jo vairāk uzṇēmumam ir patentu, jo augstāka ir

19 Cameron, G., Proudman, J., \& Redding, S. (1999). Productivity growth, convergence, and trade in a panel of manufacturing industries (No. dp0428). Centre for Economic Performance, LSE.

20 Griffith, R., Redding, S., \& Van Reenen, J. (2000). Mapping the two faces of R\&D: productivity growth in a panel of OECD industries, Centre for Economic Policy Research (No. 2457). Discussion Paper.

21 Wang, J. C., \& Tsai, K. H. (2004, June). Productivity growth and R\&D expenditure in Taiwan's manufacturing firms. In Growth and Productivity in East Asia, NBER-East Asia Seminar on Economics, 13, 277-296. University of Chicago Press.

22 Lichtenberg, F. R., \& Siegel, D. (1991). The impact of R\&D investment on productivity-New evidence using linked R\&D-LRD data. Economic inquiry, 29(2), 203-229.

23 Hall, B. H., \& Mairesse, J. (1995). Exploring the relationship between R\&D and productivity in French manufacturing firms. Journal of econometrics, 65(1), 263-293.

24 Smith, V., Dilling-Hansen, M., Eriksson, T., \& Madsen, E. S. (2004). R\&D and productivity in Danish firms: some empirical evidence. Applied Economics, 36(16), 1797-1806.

25 Zhao, Y., \& Liu, S. (2011). Effect of China's domestic patents on total factor productivity: 1988-2009. School of Statistics, Renmin University of China.

26 Cui, J., \& Li, X. (2016). Innovation and Firm Productivity: Evidence from the US Patent Data (No. 33-2016-14774). 
tā produktivitāte. Šì sakarība ir izteiktāka, ja uzṇēmuma patenti ir vairākās tehnologiskajās kategorijās.

Duguet ${ }^{27}$, pētot franču uzṇēmumu radikālās inovācijas, konstatē, ka tieši radikālie jauninājumi būtiski ietekmē KFP izaugsmi. Produktu vai procesu modifikācijai nav tiešas būtiskas ietekmes uz kopējo faktoru produktivitāti.

Starptautiskā Valūtas fonda pētnieki ${ }^{28}$ veica starpnozaru un starpvalstu pētỉjumu, analizējot 14000 uzṇēmumus 63 valstīs, un noskaidroja, ka pastāv cieša sakarība starp uzn̦ēmuma inovatīvo potenciālu (kas tika definēts kā spēja ieviest jaunus produktus, modificēt esošos produktus, kā arī spēja ieviest jaunus procesus un tehnologijas) un uzñēmuma produktivitāti. Tika secināts, ka atklātā sakarïba ir stipri izteikta tirgos, kam raksturīga augsta finanšu sektora attīstība.

$\mathrm{EBRD}^{29}$ pētījumam par inovāciju un produktivitātes sakarību jāpievērš īpaša vērība, jo tas ir fokusēts arī uz jaunattīstỉbas valstīm, kam parasti raksturīgi uzñēmumi ar vāju produktivitāti. Pētỉjuma rezultāti norāda, ka atdeve no inovācijām zemo tehnolog̣iju uzṇēmumu gadījumā parasti ir ḷoti augsta. EBRD pētnieki secina, ka, pat ieviešot jauninājumus tikai vadības sistēmās, paaugstinās darbaspēka un tādējādi arī visa uzṇēmuma produktivitāte. Vēl izteiktāks efekts vērojams, ieviešot jauninājumus visos uzṇēmuma līmeņos - produktu, procesu, mārketinga un darbības organizācijā.

Silverstovs ${ }^{30}$, analizējot P\&A ieguldījumu ietekmi uz uzṇēmuma produktivitāti, atklāj, ka attiecība starp abiem mainīgajiem ir izteikti nelineāra. Turklāt sakarỉba ir lielā mērā atkarīga no sektora specifikas: uzṇēmumi, kas darbojas augsto tehnologiiju nozarēs, izjūt ievērojamu produktivitātes paaugstinājumu, ieguldot $\mathrm{P} \& \mathrm{~A}$, bet nozarēs ar zemu tehnologisko ietilpību šis efekts nav nozìmīgs.

Bronwyn $\mathrm{H}$. Hall ${ }^{31}$ pētijumā par Eiropas ražošanas uzṇēmumiem secina, ka pastāv sakarība starp uzṇēmumu inovatīvo darbību, to produktivitātes pieaugumu un sasniegto produktivitātes līmeni. Balstoties uz šã autora analīzi, pozitīva attiecība konstatēta tikai produktu inovāciju gadījumā, taču tā netika novērota procesu inovāciju gadījumā.

27 Duguet, E. (2006). Innovation height, spillovers and TFP growth at the firm level: Evidence from French manufacturing. Economics of Innovation and New technology, 15(4-5), 415-442.

28 Verdier, G., Kersting, E., \& Dabla-Norris, M. E. (2010). Firm productivity, innovation and financial development (No. 10-49). International Monetary Fund.

29 EBRD (2014). Transition report. European bank for Reconstruction and Development. Available: https://www.ebrd.com/news/publications/transition-report/transition-report-2014.html

30 Siliverstovs, B. (2016). R\&D and non-linear productivity growth. Research Policy, 45(3), 634-646.

31 Hall, B. H. (2011). Innovation and productivity (No. 17178). National bureau of economic research. 
Tello ${ }^{32}$ savā pētỉjumā uzṇēmumu datu izlasi iedalīja augstās un zemās tehnologijias kompānijās, vienlaikus ņemot vērā uzṇēmuma lielumu, pieņemot, ka lielāki uzņēmumi, visticamāk, vairāk ieguldīs pētniecībā un attīstībā. Tello secināja, ka inovācijas būtiski ietekmē uzṇēmuma KFP, ja uzñēmums tiek klasificēts kā augsto tehnolog̣iju uzṇēmums. Lielā mērā šis faktors ir atkarīgs tieši no darbaspēka. Līdzīgus secinājumus izdarīja Fazlioglu un citi ${ }^{33}$, pētot Turcijas ražošanas uzn̦ēmumus. Autori secināja, ka pastāv lielāka varbūtība, ka uzṇēmums iesaistīsies inovatīvā darbībā, ja uzṇēmums ir lielāks, ja tas eksportē, ja izmanto ārpakalpojumus, ja uznēemuma bilancē ir vairāk nemateriālu aktīvu.

Vairums akadēmisko pētījumu l̦auj izdarì secinājumu, ka uzṇēmuma investīcijas ar mērḳi paaugstināt to inovatīvo potenciālu, visticamāk, paaugstinās uzņēmuma produktivitāti, tādējādi pozitīvi ietekmējot arī rentabilitāti un uzṇēmuma vērtības pieaugumu.

\section{Pētijuma metodologija}

\section{Izlases dati}

Lai analizētu Latvijas uzṇēmumu KFP, tās saikni ar finanšu rādìtājiem un inovatīvo potenciālu, tika izmantoti privāto un publisko uzṇēmumu dati no firmas.lv datubāzes, atlasot uzṇēmumus, kuru apgrozījums 2019. gadā bija augstāks par 145000 eiro un kuru dati bija pieejami par visu periodu no 2015. līdz 2019. gadam. No izlases tika izslēgti finanšu nozares uzṇēmumi to atšķirīgo finanšu atskaites sistēmas dēḷ. Tika izslēgti arī tie uzņēmumi, kuros darbinieku skaits ir mazāks par desmit, lai izslēgtu holdingu struktūras, kad uzṇēmumam ir milzīga peḷna, kas tiek gūta no citiem uzñēmumiem, bet pats uzñēmums saimniecisko darbību neveic. Viena perioda KFP rādītāja aprēķināšana prasa vismaz divus gadus, tāpēc KFP rādītājs uzṇēmumiem tika aprēḳināts, sākot no 2017. gada.

Izlasē iekḷautajiem uzņēmumiem tika atlasīti dati par to bruto peḷnu, kopējiem aktīviem, darbinieku skaitu, materiāliem aktīviem un kapitālieguldijumiem. Lai novērtētu uzṇēmuma produktivitāti, tika analizēta uzṇēmuma pievienotā vērtîba, kas pēc būtības ir bruto peḷna (output $-y$ ), nodarbinātība (labour - l) un fiziskais kapitāls (capital - k). Katrā pētītajā gadā uzṇēmumu skaits svārstījās datu pieejamības dēl, tādējādi analīzē par 2017. gadu tika iekḷauti 7582 uzṇēmumi, par 2018. gadu - 8121 uzņēmums, par 2019. gadu - 7809 uzņēmumi.

32 Tello, M. D. (2015). Firms' Innovation, Public Financial Support, and Total Factor Productivity: The Case of Manufactures in Peru. Review of Development Economics, 19(2), 358-374.

33 Fazlığlu, B., Dalgıç, B., \& Yereli, A. B. (2019). The effect of innovation on productivity: evidence from Turkish manufacturing firms. Industry and Innovation, 26(4), 439-460. 


\section{Kopējās faktoru produktivitātes aprēḳināšana}

Ražošanas vai pakalpojumu sniegšanas procesā tiek izmantots gan darbaspēks, gan fiziskais kapitāls, kā arī trešā nozīmīgā sastāvdaļa - KFP. Ražošanas funkcija, kurās pamatā ir Solow vienādojums ${ }^{34}$ un pēc kuras autores aprēḳina KFP, ir šāda:

$$
y_{i t}=\beta_{0}+\beta_{k} k_{i t}+\beta_{l} l_{i t}+w_{i t}+\varepsilon_{i t},
$$

kur $y_{i t}$ ir uzṇēmuma $i$ pievienotās vērtības (šajā pētijumā pieņemta kā bruto peḷna) logaritms par periodu $t$. Uzṇēmumiem, kam bija bruto zaudējumi attiecīgajos periodos, tika izslēgti no aprēķiniem. Neatkarīgie mainīgie, $k_{i t}$ un $l_{i t}$, ir darbaspēka (darbinieku skaits) un kapitāla (materiālie ieguldījumi) logaritmi. $w_{i t}$ ir uzņēmuma $i$ ražìgums par periodu $t$. $\varepsilon_{i t}$ ir statistiskā kḷ̂ùda.

Pētijumā lietota uzṇēmuma produktivitātes aprēḳināšanas metodologiija, ko izstrādāja Olley un Pakes. ${ }^{35}$ Šìs pieejas galvenā priekšrocība salīdzinājumā ar tradicionālo KFP novērtējuma metodi ir spēja kontrolēt atlasi (selection bias), jo, aprēķinot produktivitāti, tiek ṇemta vērā varbūtība, ka uzṇēmums ar noteiktu produktivitātes līmeni pārtrauks savu darbību.

Darbaspēka faktors ir vienīgais mainīgais, kura vērtību var ietekmēt uzṇēmuma ražīgums. Kapitāla faktors laika periodā $t$ ir fiksēts, taču to var ietekmēt iepriekšējo periodu ražīguma līmenis gadījumos, kad uzṇēmums pieṇem lēmumu palielināt tā investīcijas kapitālā $\left(i_{i t}\right)$. Vienādojums (2) parāda uzṇēmuma optimizācijas procesa risinājumu:

$$
i_{i t}=j\left(w_{i t}, k_{i t}\right)
$$

kur, paaugstinoties $w_{i t}$, pieaug arī $i$ un $j$. Apgrieztais vienādojums izskatās šādi:

$$
w_{i t}=h\left(i_{i t}, k_{i t}\right)
$$

No iepriekšējām vienādībām iespējams izteikt:

$$
\varphi_{i t}=\beta_{0}+\beta_{k} k_{i t}+h\left(i_{i t}, k_{i t}\right) .
$$

Izmantojot vienādojumus (1) un (4), tiek iegūts šāds vienādojums:

$$
y_{i t}=\beta_{l} l_{i t}+\varphi_{i t}+\varepsilon_{i t},
$$

$\operatorname{kur} \varphi_{i t}$ tiek aprēķināts ar otrās pakāpes polinomu, izmantojot kapitāla un investīciju radītājus. Šis ir pirmais solis uzṇēmuma KFP rādītāja aprēḳināšanā, un tiek

34 Solow, R. M. (1957). Technical Change and the Aggregate Production Function. The Review of Economics and Statistics, 39(3), 312-320.

35 Olley, G. S., and Pakes, A. (1996). The Dynamics of Productivity in the Telecommunications Equipment Industry. In: Econometrica 64 (6), 1263-1297. 
iegūts darbaspēka koeficients $\beta_{l}$. Pārejot pie otrā posma, uzmanība tiek veltīta nākotnes prognozēm, būtībā aprēḳinot, vai uzṇēmums turpinās savu darbību vai atstās izlasi. Šim nolūkam tiek izmantots šāds vienādojums:

$$
E_{t}\left(y_{i, t+1}-\beta_{l} l_{i, t+1}\right)=\beta_{0}+\beta_{k} k_{i, t+1}+g\left(w_{i t}, P_{\text {survival }, t}\right),
$$

kur $P$ ir uzṇēmuma darbības turpināšanas varbūtība laikposmā no $t$ līdz $t+1$, kas tiek aprēķināta ar Probit model̦a palīdzību.

Iegūstot $\beta_{0}, \beta_{k}$ un $\beta_{l}$, tiek aprēḳināts arī uzṇēmuma produktivitātes logaritms $w_{i t}$ :

$$
w_{i t}=y_{i t}-\beta_{0}-\beta_{k} k_{i t}-\beta_{l} l_{i t} .
$$

KFP funkciju parametri tika aprēḳināti katru gadu, izmantojot visus pieejamos datus līdz minētajam gadam.

\section{Analīzes metodologija}

Iegūstot datus par uzṇēmumu KFP 3 gadu periodā, sākumā tika novērtēta KFP rādītāju starpība reg̣ionu un nozaru griezumā ar mērḳi atklāt iespējamas likumsakarības. Nozares sadalījums balstìts uz NACE 2 klasifikāciju, reǵionālais iedalïjums veidots pēc novadiem (Latgale, Vidzeme, Zemgale, Kurzeme un Rīga), kuros uzṇēmumi ir reǵistrēti.

Lai noteiktu uzņēmumu produktivitātes saistību ar finanšu sniegumu, tika veikta KFP rādìtāju kvartiļu analīze, sasaistot to ar uzṇēmuma pašu kapitāla un saimnieciskās darbības rentabilitāti. Papildus tika analizēta KFP saistība ar uzṇēmuma ieguldījumiem nemateriālajos aktīvos, ko var uzskatīt par vienu no uzṇēmuma inovatĩvā potenciāla novērtējuma rādītājiem.

\section{Pētijjuma rezultāti}

\section{Darbaspēka un kapitāla parametri}

Veicot aprēķinus, tika iegūti produktivitātes funkcijas galvenie parametri $\beta_{k}$ un $\beta_{l}$ (1. tabula). Darbaspēka $l_{i t}$ koeficients $\beta_{l}$ ir diezgan mainīgs un svārstās robežās no 0,77 līdz 0,51 periodā no 2017. līdz 2019. gadam. Šim koeficientam ir spilgti izteikta samazināšanās tendence, tātad darbaspēka svarīgums uzṇēmuma bruto peḷnas generēšanā kḷ̂ust arvien zemāks.

Ieguldītā kapitāla $k_{i t}$ koeficients $\beta_{l}$ visos apskatītajos gados ir daudz zemāks nekā darbaspēka koeficients. Kapitāla koeficients mēdz svārstīties, tādējādi ietekmējot arī rezultējošā KFP rādītāja svārstīgumu. 2018. gada koeficienta kritums, iespējams, ir dal̦ēji skaidrojams ar uzṇēmumu ienākuma nodokḷa reformu, kas krasi uzlaboja uzņēmumu finanšu rezultātus. Reformas ietekmē uzṇēmumu 
pel̦ṇa auga straujāk nekā IKP, un uzṇēmumu kopējā faktoru produktivitāte bija krietni augstākā līmenī salīdzinājumā ar 2017. un 2019. gadu.

\section{1. tabula. Produktivitātes funkcijas galvenie parametri $\beta_{k}$ un $\beta_{l}$}

\begin{tabular}{|l|c|c|c|}
\hline \multicolumn{1}{|c|}{ Rādỉtājs } & 2017 & 2018 & 2019 \\
\hline$\beta_{l}$ & 0,766 & 0,669 & 0,505 \\
\hline$\beta_{k}$ & 0,268 & 0,13 & 0,295 \\
\hline Uzṇēmumu bruto peḷnas pieaugums (mediāna) & $6,9 \%$ & $10,5 \%$ & $3,8 \%$ \\
\hline IKP pieaugums & $5,2 \%$ & $8,1 \%$ & $4,5 \%$ \\
\hline
\end{tabular}

Avots: autoru aprēḳini pēc Eurostat un firmas.lv datiem.

Apskatot rezultātus, kas atspoguḷoti 1. tabulā var secināt, ka KFP Latvijas uzṇēmumiem pēdējos gados kḷūst arvien nozīmīgāka, samazinoties kapitāla un darbaspēka faktoru kopējam pienesumam.

\section{Latvijas uzṇēmumu produktivitātes tipologijija}

Lai analizētu vispārīgo ainu par Latvijas uzṇēmumu produktivitāti atkarībā no reǵioniem, kuros uzņēmumi ir reǵistrēti, un no nozarēm, kurās tie darbojas, datu izlases uzṇēmumi tika atbilstoši klasificēti un tiem tika aprēḳināts KFP rādītāja ikgadējā mediāna. KFP rādītājs šajā pētījumā tika aprēḳināts kā KFP attiecība pret uzṇēmuma bruto peḷnu, iegūstot relatīvu lielumu, kas ḷauj salīdzināt uzñēmumus savstarpēji neatkarīgi no to izmēra.

Uzṇēmumu produktivitātes salīdzināšana atkarībā no to darbības reǵiona sakrita ar sagaidāmajiem rezultātiem - visaugstākā uzṇēmumu produktivitāte ir novērojama Rīgas reǵionā. Uzṇēmumi ar viszemāko KFP rentabilitāti darbojas galvenokārt Kurzemes reǵionā. Rīgas uzñēmumu augstāko produktivitāti var skaidrot ar to, ka galvaspilsētā ir labāka piekḷuve augstākām tehnoloǵijām, zināšanām un labākām cilvēku prasmēm, kā arī finanšu resursiem, kas padara uzṇēmumu darbību efektīvāku un dod iespēju strādāt ar augstāku pievienoto vērtību. Kā norāda daudzi zinātnieki, piekḷuve finansējumam ir izšḳirošais faktors, lai radìtu augstu kopējo faktoru produktivitāti. ${ }^{36,37,38}$

36 Levine, O., \& Warusawitharana, M. (2014). Finance and productivity growth: Firm-level evidence. Federal Reserve Board.

37 Han, J., \& Shen, Y. (2015). Financial development and total factor productivity growth: Evidence from China. Emerging Markets Finance and Trade, 51(sup1), S. 261-274.

38 Lasagni, A., Nifo, A., \& Vecchione, G. (2015). Firm productivity and institutional quality: Evidence from Italian industry. Journal of Regional Science, 55(5), 774800. 
2. tabula. Uzṇēmumu kopējās faktoru produktivitātes rādītājs pēc regiona klasifikācijas

\begin{tabular}{|l|c|c|c|}
\hline \multicolumn{1}{|c|}{ Reǵions } & $\mathbf{2 0 1 7}$ & $\mathbf{2 0 1 8}$ & $\mathbf{2 0 1 9}$ \\
\hline Rīga & $0,47 \%$ & $2,85 \%$ & $0,78 \%$ \\
\hline Pierīga & $0,38 \%$ & $2,51 \%$ & $0,67 \%$ \\
\hline Kurzeme & $0,34 \%$ & $2,40 \%$ & $0,59 \%$ \\
\hline Latgale & $0,41 \%$ & $2,74 \%$ & $0,69 \%$ \\
\hline Vidzeme & $0,36 \%$ & $2,55 \%$ & $0,62 \%$ \\
\hline Zemgale & $0,35 \%$ & $2,46 \%$ & $0,62 \%$ \\
\hline
\end{tabular}

Avots: autoru aprēķini pēc firmas.lv datiem.

Apskatot KFP rādītāju nozaru sadalījumā, var identificēt nozares, kuras gandrīz visa analizētajā periodā ien̦ēma augstākas pozịcijas, kā arī tās, kas pārsvarā uzrādīja zemākus rezultātus. Pie līderu nozarēm var pieskaitīt: 1) profesionālos, zinātniskos un tehniskos pakalpojumus; 2) IT un komunikāciju pakalpojumus; 3) tirdzniecību; 4) būvniecību. Diezgan negaidīti rezultāti tika iegūti par izmitināšanas un èdināšanas pakalpojumu nozari, jo pretēji sagaidītajam šīs nozares pārstāvjiem ir relatīivi augsts KFP rādītājs.

Turpinot par vadošajām nozarēm, var atzīmēt kopējā apgrozìjuma pieaugumu un labvēlīgos tirgus apstākḷus, kas sekmēja augstāku produktivitāti tirdzniecības un būvniecības uzṇēmumiem, kā arī izmitināšanas nozarei. Turklāt jāṇem vērā arī 2018. gada nodokḷu reforma, kas palīdzēja uzṇēmumiem uzlabot finansiālo stāvokli un attiecīgi arī to produktivitāti. Augsts KFP rādìtājs uzṇēmumiem, kas sniedz IT un zinātniski tehniskus pakalpojumus, ir skaidrojams ar augstu zināšanu ietilpīgumu un inovāciju potenciālu, kas paredz augstāku pievienoto vērtību un tādējādi arī augstāku ražìgumu.

Pie nozarēm, kas uzrādīja zemākos KFP rādītājus apskatītājā periodā, ir pieskaitāmas: 1) ūdens apgāde un atkritumu apsaimniekošana; 2) elektroenerğijas un gāzes apgāde; 3) ieguves rūpniecība; 4) lauksaimniecība un mežsaimniecība. Tiesa, komunālo pakalpojumu sniedzējiem jauninājumu potenciāls ir diezgan zems, un tādējādi uzṇēmumu produktivitāti ir grūti paaugstināt. Lauksaimniecības nozare, kas saṇem lielas subsīdijas, uzrāda diezgan zemu produktivitāti, salīdzinot ar vidējiem rādītājiem, kaut gan tajā konstanti tiek ieviesti jauni risinājumi, kas teorētiski l̦autu produktivitāti paaugstināt. Šo fenomenu iesakāms pētīt padziḷināti, noskaidrojot, kādi iekšējie vai ārējie faktori varētu to ietekmēt. 
3. tabula. Uzṇēmumu kopējās faktoru produktivitātes rādītājs pēc nozaru klasifikācijas

\begin{tabular}{|c|c|c|c|}
\hline Nozare pēc NACE 2.0 klasifikācijas & 2017 & 2018 & 2019 \\
\hline Lauksaimniecība, mežsaimniecība un zivsaimniecība & $0,2 \%$ & $2,0 \%$ & $0,4 \%$ \\
\hline leguves rūpniecība un karjeru izstrāde & $0,2 \%$ & $1,8 \%$ & $0,4 \%$ \\
\hline Apstrādes rūpniecība & $0,3 \%$ & $2,2 \%$ & $0,6 \%$ \\
\hline Elektroenergiija, gāzes apgāde, siltumapgāde un gaisa kondicionēšana & $0,2 \%$ & $1,6 \%$ & $0,2 \%$ \\
\hline Ūdens apgāde; notekūdeņu, atkritumu apsaimniekošana un sanācija & $0,1 \%$ & $1,4 \%$ & $0,3 \%$ \\
\hline Būvniecība & $0,5 \%$ & $3,0 \%$ & $0,8 \%$ \\
\hline $\begin{array}{l}\text { Vairumtirdzniecība un mazumtirdzniecība; automobil̦u un motociklu } \\
\text { remonts }\end{array}$ & $0,5 \%$ & $3,0 \%$ & $0,8 \%$ \\
\hline Transports un uzglabāšana & $0,3 \%$ & $2,5 \%$ & $0,6 \%$ \\
\hline Izmitināšanas un ēdināšanas pakalpojumi & $0,6 \%$ & $3,1 \%$ & $1,0 \%$ \\
\hline Informācijas un komunikācijas pakalpojumi & $0,5 \%$ & $3,0 \%$ & $0,9 \%$ \\
\hline Operācijas ar nekustamo īpašumu & $0,3 \%$ & $2,4 \%$ & $0,5 \%$ \\
\hline Profesionālie, zinātniskie un tehniskie pakalpojumi & $0,6 \%$ & $3,6 \%$ & $1,0 \%$ \\
\hline Administratīvo un apkalpojošo dienestu darbība & $0,4 \%$ & $2,3 \%$ & $0,8 \%$ \\
\hline Veselība un sociālā aprūpe & $0,4 \%$ & $2,6 \%$ & $0,7 \%$ \\
\hline
\end{tabular}

Avots: autoru aprēķini pēc firmas.lv datiem.

\section{Saikne starp uzñēmuma produktivitāti un uzṇēmumu kapitāla un saimnieciskās darbības rentabilitāti}

Pētījumā tika apskatīta saikne starp uzṇēmumu KFP un pašu kapitāla izmantošanas efektivitāti, sadalot uzņēmumu kopu četrās grupās (kvartilēs), pamatojoties uz KFP rādītāju, kas tika aprēķināts ik gadu. No 1. attēlā atspoguḷotajiem rezultātiem var secināt, ka uzṇēmumiem, kuri atrodas 4 . kvartilē pēc KFP rādītāja (augstākā produktivitāte), ir arī attiecīgi visaugstākā pašu kapitāla rentabilitāte, kas īpaši izteikti ir redzams 2018. un 2019. gadā. Vienīgi 2017. gadā augstāks rentabilitātes līmenis bija uzṇēmumiem, kas atrodas 3. kvartilē, tomēr šī atškịirība bija statistiski nebūtiska. Attiecībā uz uzṇēmumiem, kas atrodas 1. un 2. kvartilē, rezultāts ir logisks un stabils - uzṇēmumiem ar viszemāko KFP ir arī viszemākā aktīvu pārvaldības efektivitāte, t. i., viszemākais peḷnas apjoms uz vienu ieguldīto eiro pašu kapitālā, kas ir vissvarīgākais rādītājs uzṇēmuma akcionāram.

Diezgan atšḳirīgs ir uzṇēmumu operacionālās pelnītspējas sadalījums pēc to produktivitātes kvartilēm. Augstākā rentabilitāte piemīt uzṇēmumiem ar vidējo produktivitātes līmeni, t. i., tiem uzṇēmumiem, kas ierindojas 2. kvartilē. 2018. gadā augstāko rentabilitātes līmeni sasniedza arī uzṇēmumi, kas ietilpst 
1. attēls. Uzṇēmumu pašu kapitāla rentabilitāte pēc KFP kvartilēm

(1. kvartile - zemākā KFP, 4. kvartile - augstākā KFP)

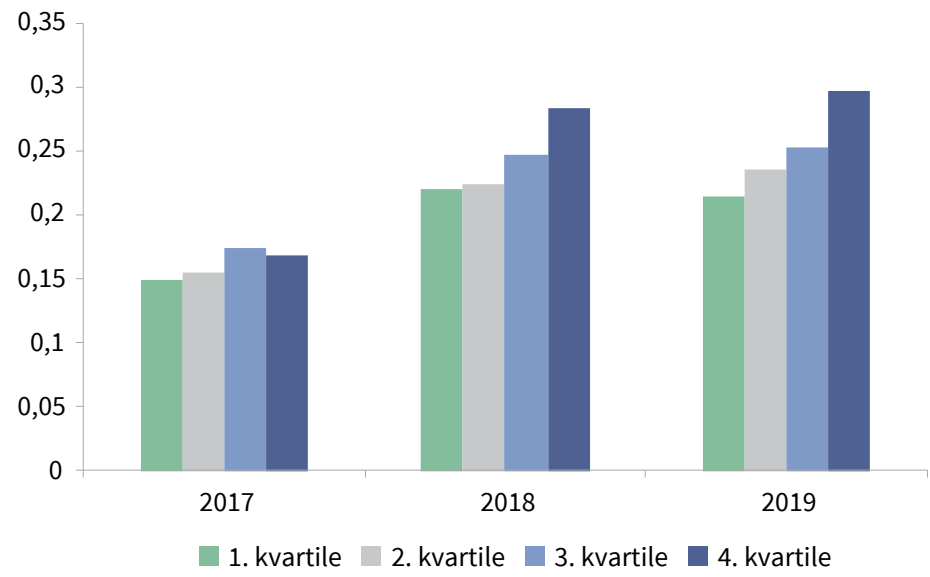

2. attēls. Uzṇēmumu saimnieciskās darbības rentabilitāte pēc KFP kvartilēm

(1. kvartile - zemākā KFP, 4. kvartile - augstākā KFP)

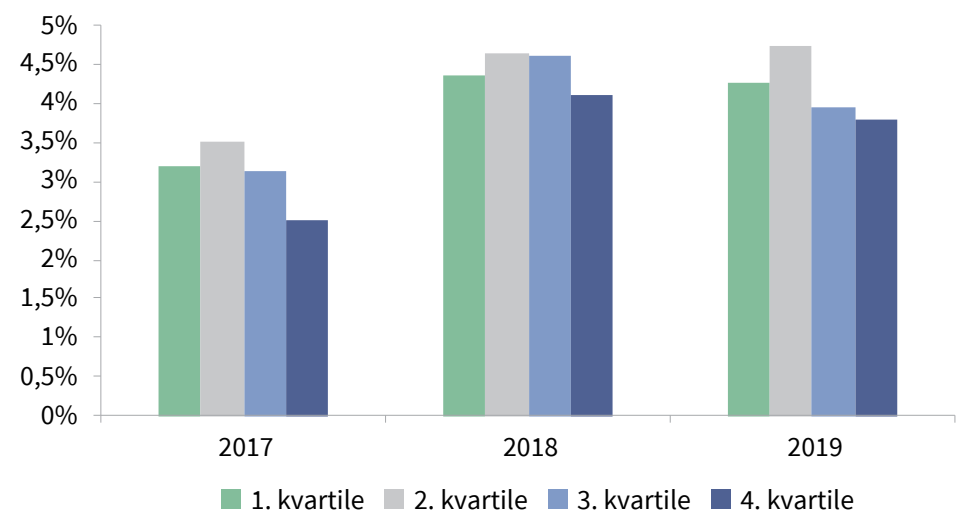

3. kvartilē pēc KFP līmeņa. Balstoties uz iegūtajiem rezultātiem, zemākā saimnieciskās darbības rentabilitāte ir uzṇēmumiem, kam ir raksturīga zema produktivitāte. Šo rezultāti daļêji var izskaidrot ar to, ka augstākās produktivitātes kvartilē ir daudz uzṇēmumu, kas darbojas tirdzniecības nozarē, kur zema operacionālā pelnītspēja ir l̦oti izplatīta. 
N̦emot vērā minēto, ir redzams, ka tie uzņēmumi, kam ir augstākā produktivitāte, ir spējīgi uzrādīt arī augstāku kapitāla atdevi, taču šis parādības endogenitāte šajā pētījumā netiek apskatīta. Runājot par uzņēmuma operacionālo pelnītspēju, pētijumā netika novērota izteikta saikne starp uzṇēmuma produktivitāti un rentabilitāti, tātad, balstoties uz izmantotajiem datiem un uzñēmumu atlasi, saimnieciskās darbības rentabilitāti nevar skaidrot ar izmaiṇām kopējā faktoru produktivitātē.

\section{Produktīvākie uzṇēmumi un to inovatīvais potenciāls}

Iegūtie uzṇēmumu KFP dati tika salīdzināti ar uzṇēmumu ieguldījumiem nemateriālajos aktīvos, lai noteiktu inovatīvā potenciāla pakāpi, ko dalẹji iespējams novērtēt, balstoties uz nemateriālo aktīvu proporciju kopējos aktīvos.

No kvartiḷu analīzes (3. attēls) redzams, ka uzṇēmumi, kuriem ir augstākais KFP radītājs, neuzrāda proporcionāli lielākus ieguldījumus nemateriālajos aktīvos. To līmenis ir salīdzināms ar visas uzņēmumu kopas līmeni. Izṇēmums ir uzņēmumi, kas atrodas KFP radītāja 1. kvartilē, jo to ieguldījumi nemateriālajos aktīvos ir daudz augstāki nekā pārējie visos apskatītajos periodos. Šie novērojumi neapstiprina iepriekšējo pētījumu rezultātus, ka produktīvāki uzṇēmumi ir arī inovatīvāki. Atšksirības rezultātos var skaidrot ar to, ka nemateriālie ieguldījumi ir visai vājš inovatīvā potenciāla noteicējs. Iespējams, ka produktivitāte iepriekšējo pètījumos tika aprēķināta pēc citas metodologijas.

3. attēls. Uzṇēmumu nemateriālie ieguldījumi pret kopējiem aktīviem pēc KFP kvartilēm (1. kvartile - zemākā KFP, 4. kvartile - augstākā KFP)

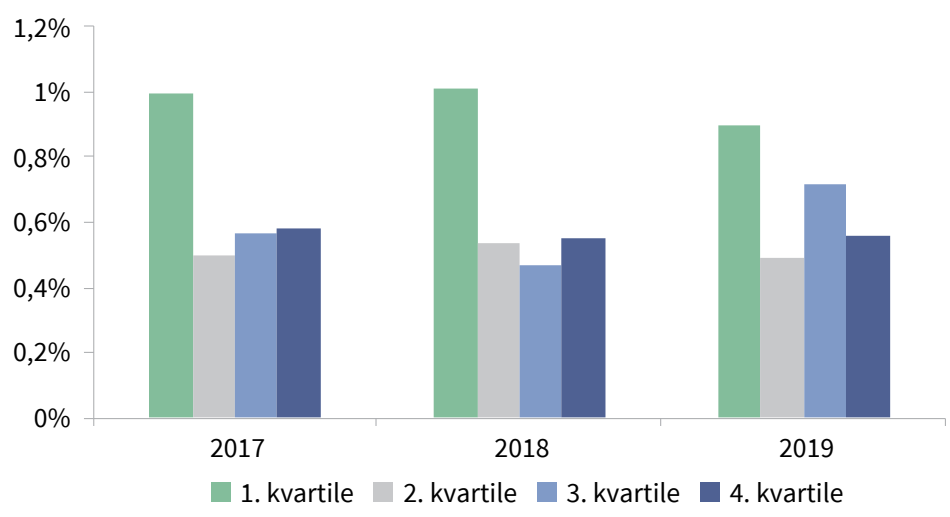




\section{4. attēls. Uzṇēmumu nemateriālie ieguldijumi pret kopējiem aktīviem pēc "bruto peḷnas} uz 1 darbinieku” kvartilēm (1. kvartile - zemākā bruto peļ̦na, 4. kvartile - augstākā bruto pelına)

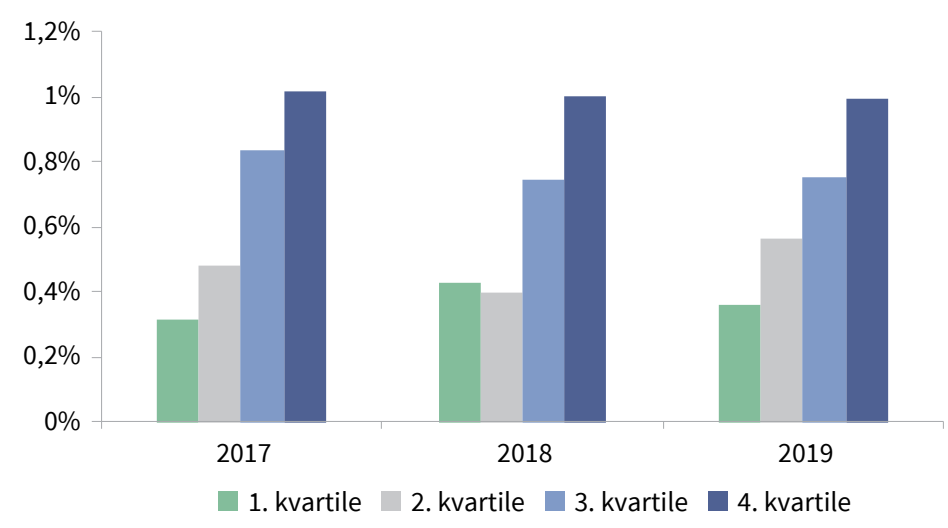

Salīdzinājumam tika aprēḳināts arī produktivitātes rādītājs pēc citas metodolog̣ijas, kas tiek rēḳināts kā bruto peḷna uz vienu darbinieku (4. attēls). Šajā gadījumā ir skaidri redzams, ka produktīvākiem uzṇēmumiem pēc šìs metodologiijas ir augstāki ieguldījumi nemateriālajos aktīvos.

\section{Secinājumi}

Globālā konkurence starp uzṇēmumiem palielinās ik dienu, tāpēc tiekšanās uz konkurētspējīgu un ilgtspējīgu darbību ir ḷoti vēlama, jo šie faktori spēj veicināt augstāku uzṇēmumu vērtību ilgtermiņā. Konkurētspēja ir sasniedzama, ieviešot jauninājumus, ieguldot $\mathrm{P} \& \mathrm{~A}$, mārketingā un nemateriālajā kapitālā, līdz ar to veicinot arī augstāku uzṇēmumu produktivitāti. Analizējot Latvijas uzṇēmumu rādītāju dinamiku, tika secināts, kādā veidā noteikt produktivitātes sakarību ar uzṇēmumu rentabilitātes radītājiem un to inovatīvo potenciālu un kāda ir KFP specifika nozaru un reǵionu griezumā.

Kopējā faktoru produktivitāte Latvijas uzṇēmumiem kḷūst arvien svarīgāka, jo darbaspēka un fiziskā kapitāla faktoru kopsummas ietekmei ir tendence samazināties. Šiem vēsturiski nozīmīgajiem faktoriem vairs nav tik lielas ietekmes uz uzņēmumu produktivitāti kā senāk, kas arī atbilst globālai tendencei.

Ir atšķirība starp Rīgas uzṇēmumu vidējo produktivitāti un to uzṇēmumu produktivitāti, kas darbojas reǵionos, ko var vismaz daḷeji skaidrot ar labāku 
pieeju finansējumam un izglītotākam darbaspēka resursam. Visaugstākā produktivitāte ir tirdzniecībā un būvniecībā, kā arī zinātniski tehnisko pakalpojumu un IT nozarē. Var pieṇemt, ka IT gadījumā inovatīvais potenciāls ir diezgan augstā līmenī, taču pastāv šaubas attiecībā uz tirdzniecības sektoru, kur augstā produktivitāte varētu būt citu, analīzē neiekḷautu, faktoru ietekmes rezultāts. Zema produktivitāte ir vērojama komunālo pakalpojumu uzṇēmumu vidū, kam parasti ir grūti paaugstināt produktivitāti darba specifikas dẹl. Šai nozarei ir raksturīga augsta kapitāla intensitāte, tāpat kā ražošanai, līdz ar to secināms, ka šì nozare prasa ievērojamu aktīvu bāzi, kas neḷauj sasniegt augstu produktivitātes līmeni, turklāt jauninājumu potenciāls šajā nozarē ir diezgan zemā līmenī.

Sasaistot iegūtos KFP rādītājus ar uzṇēmumu pašu kapitāla un saimnieciskās darbības rentabilitāti, lai pārbaudītu, vai produktīvākie uzņēmumi spēj uzrādīt arī labāko finanšu sniegumu, tika secināts, ka produktīvākajiem uzṇēmumiem piemīt arī augstāka kapitāla atdeve. Tomēr, balstoties uz iegūtajiem rezultātiem, nebija iespējams secināt, ka augsta operacionālā pelnītspēja ir raksturīga produktīvākiem uzṇēmumiem. Labākais sniegums ir uzṇēmumiem ar vidēja līmeņa rentabilitāti. Analizējot uzṇēmumu KFP rādītāju un to inovatīvo potenciālu, kas tika aprēḳināts, vadoties pèc ieguldījumiem nemateriālajos aktīvos, netika secināts, ka produktīvākiem uzņēmumiem ir augstāki ieguldījumi nemateriālajos aktīvos. Kad produktivitātes rādītājs tika rēḳināts kā bruto peḷna uz darbinieku, tad bija iespējams secināt, ka produktīvākiem uzṇēmumiem ir augstāki ieguldījumi nemateriālajos aktīvos.

Autores uzskata, ka būtu lietderīgi atkārtot šo pētījumu pēc dažiem gadiem, kad uzṇēmumu vadītāji, iespējams, vairāk apzināsies ieguldījumu svarīgumu P\&A un sāks piedāvāt vairāk produktu un pakalpojumu ar augstāku pievienoto vērtību. Papildus būtu nepieciešams veikt salīdzinošu analīzi starp Baltijas valstīm, kā arī ar uzṇēmumiem no Rietumeiropas. 